Prepared for:

Portland General Electric, Portland, OR

U.S. Fish and Wildlife Service, Oregon Fish and Wildlife Office, Portland, OR

Bureau of Reclamation, Lower Columbia Area Office, Portland, OR

Confederated Tribes of the Grand Ronde, Portland Office, Portland, OR

\title{
Passage and Behavior of Radio-Tagged Adult Pacific Lamprey (Entosphenus tridentata) at the Willamette Falls Project, Oregon, 2005-07
}

Open-File Report 2009-1223 



\section{Passage and Behavior of Radio-Tagged Adult Pacific Lamprey (Entosphenus tridentata) at the Willamette Falls Project, Oregon, 2005-07}

Matthew G. Mesa, U.S. Geological Survey; Robert J. Magie, Pacific States Marine Fisheries Commission; and Elizabeth S. Copeland, U.S. Geological Survey

Prepared for:

Portland General Electric, Portland, OR

U.S. Fish and Wildlife Service, Oregon Fish and Wildlife Office, Portland, OR Bureau of Reclamation, Lower Columbia Area Office, Portland, OR Confederated Tribes of the Grand Ronde, Portland Office, Portland, OR

Open-File Report 2009-1223

U.S. Department of the Interior U.S. Geological Survey 


\section{U.S. Department of the Interior KEN SALAZAR, Secretary}

\section{U.S. Geological Survey \\ Suzette M. Kimball, Acting Director}

U.S. Geological Survey, Reston, Virginia: 2009

For more information on the USGS-the Federal source for science about the Earth, its natural and living resources, natural hazards, and the environment, visit $h t t p: / / u w w . u s g s . g o v$ or call 1-888-ASK-USGS.

For an overview of USGS information products, including maps, imagery, and publications, visit http://huw.usgs.gov/pubprod

To order this and other USGS information products, visit http://store.usgs.gov

Suggested citation:

Mesa, M.G., Magie, R.J., and Copeland, E.S., 2009, Passage and behavior of radio-tagged adult Pacific lamprey (Entosphenus tridentata) at the Wilamette Falls Project, Oregon, 2005-07: U.S. Geological Survey Open-File Report 2009-1223, 28 p.

Any use of trade, product, or firm names is for descriptive purposes only and does not imply endorsement by the U.S. Government.

Although this report is in the public domain, permission must be secured from the individual copyright owners to reproduce any copyrighted material contained within this report. 


\section{Contents}

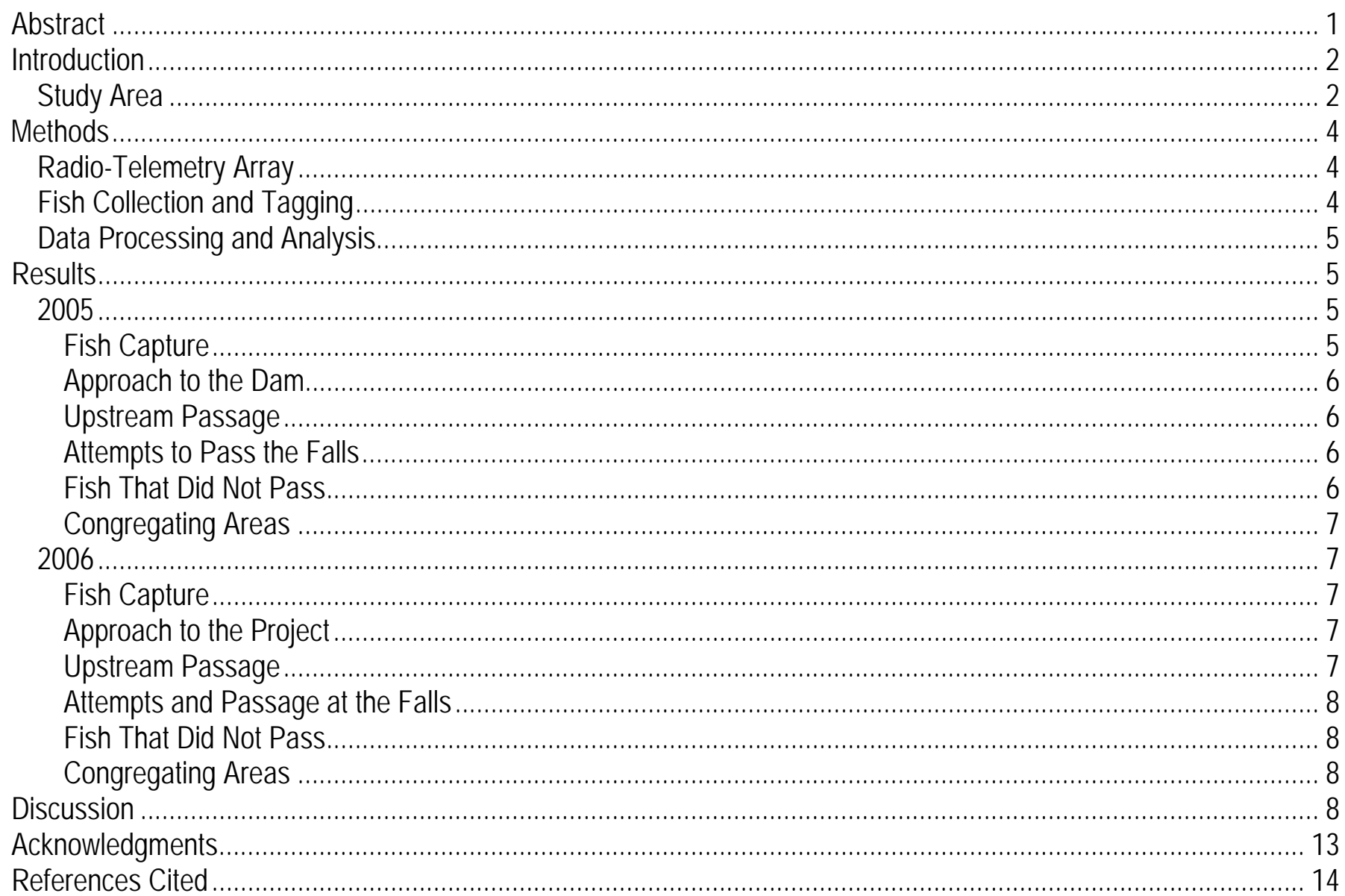

\section{Figures}

Figure 1. Overview of study area on the Willamette River, Oregon

Figure 2. Photograph of the Willamette Falls Project, Oregon, showing three general areas monitored during telemetry studies, 2005-07.

Figure 3. Schematic drawing of the Willamette Falls Project, Oregon, showing the location

of aerial (triangles) and underwater (circles) antennas for the telemetry array used for monitoring lamprey passage

Figure 4. Daily mean discharge $\left(\mathrm{m}^{3} / \mathrm{s}\right)$ and water temperature $\left({ }^{\circ} \mathrm{C}\right)$ at the Willamette Falls Project for 2005-06

Figure 5. Hour of the day or night (Pacific Standard Time) when radio-tagged Pacific lampreys were first detected as they approached the Willamette Falls Project, Oregon, 2005-06 .....

Figure 6. Mean daily temperature $\left({ }^{\circ} \mathrm{C}\right)$, discharge (kcfs), and lamprey passage by week at the Willamette Falls Project, Oregon, 2005

Figure 7. Passage efficiency of Pacific lampreys by route (that is, the fishways or the falls; the number of fish that successfully passed divided by the number that attempted to pass) and for lampreys overall (the number that successfully passed divided by the number that approached the Project) at the Willamette Falls Project, Oregon, 2005-06 


\section{Figures-Continued}

Figure 8. Attempts by 17 radio-tagged Pacific lampreys to ascend Willamette Falls, Oregon, 2005................... 25 Figure 9. Duration of detection at Willamette Falls Project for Pacific lampreys that did not pass the Project and eventually migrated downstream in 2005.

Figure 10. Mean daily temperature $\left({ }^{\circ} \mathrm{C}\right)$, discharge $\left(\mathrm{m}^{3} / \mathrm{s}\right)$, and lamprey passage by week at the Willamette Falls Project, Oregon, 2006. The dashed line denotes closure of the T.W. Sullivan Powerhouse on June 9

Figure 11. Attempts by 19 radio-tagged lampreys to ascend Willamette Falls, Oregon, 2006

\section{Tables}

Table 1. Number, mean ( \pm SD) length, range of lengths (cm), mean weights $(\mathrm{g})$, and sex ratio of Pacific lampreys that were sampled, radio-tagged, and successfully passed at the Willamette Falls Project, Oregon, 2005-06.

Table 2. Number of Pacific lampreys that were radio-tagged and released downstream of the Willamette Falls Project, Oregon, the number that approached the Project, and the median, range, and standard deviation of travel times (in hours unless specified) from release to first detection, 2005-06.

Table 3. Number of radio-tagged Pacific lampreys that passed over the Willamette Falls Project, Oregon, and the median, range, and standard deviation (SD) of passage time (in hours unless specified) by route, 2005-06.

Table 4. Location of last detection of radio-tagged Pacific lamprey at the Willamette Falls Project, Oregon, 2005-06.

Table 5. Median, mean, and range of time (days) spent by radio-tagged Pacific lampreys in areas of the Willamette Falls Project, Oregon, 2005.

Table 6. Median, mean, and range of time (days) spent by radio-tagged Pacific lampreys in areas of the Willamette Falls Project, Oregon, 2006 


\section{Conversion Factors, Acronyms, and Abbreviations}

Inch/Pound to SI

\begin{tabular}{lll}
\hline Multiply & By & To obtain \\
\hline foot per second $(\mathrm{ft} / \mathrm{s})$ & Length & \\
\hline
\end{tabular}

SI to Inch/Pound

\begin{tabular}{lcl}
\hline \multicolumn{1}{c}{ Multiply } & By & \multicolumn{1}{c}{ To obtain } \\
\hline & Length & \\
\hline centimeter $(\mathrm{cm})$ & 0.3937 & inch (in.) \\
meter (m) & 3.281 & foot (ft) \\
kilometer $(\mathrm{km})$ & 0.6214 & mile (mi) \\
cubic meter per second $\left(\mathrm{m}^{3} / \mathrm{s}\right)$ & 35.31 & cubic foot per second (ft $\left.{ }^{3} / \mathrm{s}\right)$ \\
gram (g) & 0.03527 & ounce, avoirdupois $(\mathrm{oz})$ \\
\hline
\end{tabular}

Temperature in degrees Celsius $\left({ }^{\circ} \mathrm{C}\right)$ may be converted to degrees Fahrenheit $\left({ }^{\circ} \mathrm{F}\right)$ as follows: ${ }^{\circ} \mathrm{F}=\left(1.8 \times^{\circ} \mathrm{C}\right)+32$

Temperature in degrees Fahrenheit $\left({ }^{\circ} \mathrm{F}\right)$ may be converted to degrees Celsius $\left({ }^{\circ} \mathrm{C}\right)$ as follows: ${ }^{\circ} \mathrm{C}=\left({ }^{\circ} \mathrm{F}-32\right) / 1.8$

\section{Acronyms and Abbreviations}

$\begin{array}{lc}\text { ALPP } & \text { Adult Lamprey Passage Plan } \\ \text { D } & \text { day } \\ \text { FERC } & \text { Federal Energy Regulatory Commission } \\ \text { H } & \text { hour } \\ \text { PGE } & \text { Portland General Electric } \\ \text { USGS } & \text { U.S. Geological Survey }\end{array}$


This page left intentionally blank 


\title{
Passage and Behavior of Radio-Tagged Adult Pacific Lamprey (Entosphenus tridentata) at the Willamette Falls Project, Oregon, 2005-07
}

Matthew G. Mesa, U.S. Geological Survey; Robert J. Magie, Pacific States Marine Fisheries Commission; and Elizabeth S. Copeland, U.S. Geological Survey

\begin{abstract}
We used radio telemetry to monitor passage and describe behavior characteristics of adult Pacific lampreys, Entosphenus tridentata, during their upstream migration at the Willamette Falls Project (Project) on the Willamette River near Portland, Oregon. Our objectives were to document: (1) specific routes of passage at the dam and falls; (2) duration of passage through different routes; and (3) overall passage success. During the spring through autumn of 2005 and 2006, fish were captured in a trap located in the fishway at the Project or collected by hand from the falls, surgically implanted with a radio tag, and released 2 kilometers downstream of the Project. We radio tagged 136 lampreys in 2005 and 107 in 2006. In both years, more than 90 percent of the fish returned to the Project with a median travel time of 7-9 hours. Most fish were first detected at the Project from about 20:00-23:00 hours. In 2005, 43 fish (35 percent) successfully passed through the fishway of the Project, which has four separate entrances and three distinct passage channels or legs that converge at one exit. Prior to the installation of flashboards around the perimeter of the falls in July, lampreys used all three legs of the fishway to pass the Project. After flashboards were installed, only fishway leg 1 was used. The peak of passage occurred in August. No fish passed over the falls, but 13 percent of the lampreys that traveled to the Project ascended at least partway up the falls. In 2006, 24 fish (23 percent) passed the Project, again primarily using fishway leg 1 . Most fish passed prior to June 9 when the powerhouse was shut down due to construction. Although 19 lampreys ascended the falls, only 2 passed through this route in late June and early July. Flashboards were not installed in 2006. For both years, the time it took for fish to pass through the fishway depended on which leg they used - the median passage time was at least 4-5 hours in fishway legs 2 and 3 and ranged from 23 to 74 hours in fishway leg 1. Many fish resided in the tailrace for times ranging from a few hours to almost a year and eventually left the Project and moved downstream. Collectively, our results indicate that passage of radio-tagged upstream migrating Pacific lamprey at the Willamette Falls Project is relatively poor compared to passage success of these fish at dams on the Columbia River. Factors contributing to the low passage of lampreys at the Project may include low flows and water levels at fishway entrances, impediments in the fishways, delayed tagging effects, changing environmental and operational conditions, a learned aversion to a fishway, difficult passage over the falls, or not all lamprey are destined to migrate upstream of the falls.
\end{abstract}




\section{Introduction}

Populations of Pacific lamprey (Entosphenus tridentata) in the Columbia River basin have been decreasing since the 1960s. In the Columbia and Snake River systems, counts of upstream migrating adult lampreys at dams have decreased significantly (Close and others, 1995). Willamette Falls, on the Willamette River near Portland, Oregon, has been an important Native American fishing location for thousands of years and many Tribes harvested lamprey there. Historically, the Willamette River was an important production area for Pacific lamprey in the Columbia River basin and recorded harvests from the falls often exceeded the counts of adult lamprey passing Bonneville Dam (Kostow, 2002). However, harvest of lamprey at the falls has decreased since the mid-1940s (Kostow, 2002), which resulted in the elimination of commercial collection permits and reduction of the personal and Native American harvests. Reasons for the decrease of lamprey throughout the basin include artificial barriers to migration, poor water quality, contaminants, excessive harvest, altered predator-prey interactions, loss of estuarine habitat, decline of prey, ocean conditions, dredging operations, and dewatering of streams (Close and others, 1995; Renaud, 1997).

Many lampreys returning from the Pacific Ocean travel up the Columbia River, enter the Willamette River, and congregate downstream of the falls en route to over-wintering and spawning areas. The Willamette Falls Project (Project) is a hydroelectric facility adjacent to and incorporating the falls that may hinder the upstream migration of lampreys. In some earlier studies of lamprey passage at the Project, Hanson and Mathur (2002) reported that 9 of 47 (19 percent) radio-tagged lampreys passed upstream and Ward and others (2005) documented passage success to be 50 percent in 2003 (6 of 12 tagged fish) and 38 percent in 2004 (11 of 29 fish). However, the small sample sizes used in these studies, the limited time over which tagging was conducted, some questionable methodologies (for example, holding fish for 2 weeks prior to tagging and release), variability in the migration behavior of lampreys, and the sometimes equivocal data regarding upstream passage (particularly in Hanson and Mathur, 2002) indicates that caution should be used when interpreting these results. Portland General Electric (PGE) owns and operates the Project and, as part of its Federal Energy Regulatory Commission (FERC) relicensing process, has developed and funded an Adult Lamprey Passage Plan (ALPP). Part of the ALPP mandates that more research be conducted on the behavior and passage characteristics of adult Pacific lamprey at the Project. To address this goal, we used radio telemetry to monitor the movements and behavior of Pacific lamprey during their upstream migration in 2005-06. Specifically, our objectives were to: (1) determine the specific routes of passage at the dam and falls; (2) document the duration of passage through different routes and overall passage success; and (3) identify any potential barriers to adult Pacific lamprey passage.

\section{Study Area}

The Willamette Falls Project is $41 \mathrm{~km}$ upstream of the confluence of the Willamette and Columbia Rivers in northwest Oregon (figs. 1 and 2). The Project is comprised of the concrete dam, spillway, outer intakes, and forebay, including penstocks and siphon spillway, and powerhouse. A 1.8 to 6.0-m-high concrete dam runs along the top of the horseshoe-shaped falls that allows spill of water over its entire $701 \mathrm{~m}$ length. In the summer, usually during low flows, 0.6-m-high wooden flashboards are installed along the dam to divert water away from the falls and into the powerhouse. The falls have a total drop of about $13 \mathrm{~m}$. 
Migrating adult Pacific lampreys can theoretically pass the Project in one of three ways: via fishways, the falls, or through the navigation lock. The Project has a fishway, comprised of three legs, or channels, constructed of step pool weirs, with four separate entrances. The entrance to fishway leg 1 is in the southwest corner of the cul-de-sac area near the T.W. Sullivan powerhouse tailrace and receives discharge from turbine unit 1 to provide attraction flow. The entrance to fishway leg 2 is on the west side of the falls and fishway leg 3 has two entrances near the southwest corner of the falls. Attraction water for the three entrances near the falls comes from intakes in the forebay and fish access to these entrances can depend on tailrace level. All fishway legs converge at an area called pool 48 and lead to a common fish viewing window and exit channel to the forebay (fig. 3).

In 2005, operations at the Project were normal, with substantial flow going through the powerhouse and fishway. Flashboards were set in place around the perimeter of the falls during midJuly. Thus, our research in 2005 assessed the performance and behavior of lampreys during fairly typical operations at the Project. In 2006, operating conditions at the Project were atypical because of construction of a new fish bypass system at the powerhouse. This construction, which began in June, required the following changes to normal Project operations: (1) flow through the powerhouse was shut off, (2) there were no flashboards installed at the apex of the falls, and (3) attraction flow (from the powerhouse) to fishway 1 was reduced. These changes presented unusual passage conditions for lampreys at the Project and provided an opportunity to study the effects of different operations on lamprey passage and behavior.

Discharge at Willamette Falls was calculated by summing the discharges from U.S. Geological Survey (USGS) gaging stations for the Willamette River at Newburg, Oregon, the Molalla River, the Pudding River, and the Tualatin River (T. Herrett and R. Kittleson, U.S. Geological Survey, oral commun., January 23, 2006). Willamette River discharge at the falls in 2005 ranged from 201 to 4,519 $\mathrm{m}^{3} / \mathrm{s}$ with peak flows in December (fig. 4). In 2006, discharge over the falls ranged from 187 to 4,519 $\mathrm{m}^{3} / \mathrm{s}$ with peak flows in January. Water temperatures ranged from 2.7 to $23.4^{\circ} \mathrm{C}$ in 2005 and from 3.0 to $25.0^{\circ} \mathrm{C}$ in 2006. Peak temperatures for both years coincided with low flows in July and August (fig. 4). 


\section{Methods}

\section{Radio-Telemetry Array}

We used radio telemetry to monitor the passage and behavior of lampreys at the Project during their upstream migration. We deployed an array of 14 automated radio receivers that detected fish movements from $2 \mathrm{~km}$ downstream of the falls to $1 \mathrm{~km}$ upstream of the falls (fig. 1). We strategically placed and tuned Yagi antennas in this area to detect the movements of lampreys in several general areas, including: (1) our release point, about $2 \mathrm{~km}$ downstream of the Project near the I-205 bridge; (2) an area just downstream of the Project near the Blue Heron paper mill; (3) the cul-de-sac or tailrace downstream of the powerhouse; (4) several general areas on the east and north sides of the falls; (5) the navigation lock; and (6) an area spanning the river about $1 \mathrm{~km}$ upstream of the Project. Beacon tags were placed near the aerial antennas to broadcast a signal every hour to ascertain if the receivers were working properly. Underwater antennas were placed at the entrances of fishway legs 1 and 2 and midway through fishway leg 3 upstream of both entrances to this fishway (fig. 3). Because of high water, we could not access the two entrances of fishway leg 3 to place antennas. Additional underwater antennas were placed at the end of each fishway leg, at pool 48 where the fishway legs converge, and at the entrance and exit of the fish viewing window. Telemetry equipment received radio signals between 142.0 and $150.5 \mathrm{MHz}$ and data were collected 24 hours a day, 7 days a week, with receivers downloaded every 2 weeks.

\section{Fish Collection and Tagging}

Adult lampreys were captured in a trap placed in pool 48 of the fishway during late April to midSeptember of 2005 and 2006. The lamprey trap was similar to the one used by Moser and others (2002a) but was modified for our use. We deployed the trap 4 days per week or until six lampreys were collected that met our minimum size requirements for tagging (that is, a girth of $11 \mathrm{~cm}$, measured $0.5 \mathrm{~cm}$ anterior of the first dorsal fin). The girth requirement was based on earlier work by us and recommendations by other researchers in the basin. To examine the behavior of fish that did not enter the fishway, we collected (by hand) a small sample of lampreys from the base of Willamette Falls and tagged them in late July and early August 2005 and September 2006.

Lampreys were surgically implanted with coded radio transmitters (Lotek Engineering, Inc., model NTC-6-2; weight of $4.5 \mathrm{~g}$ in air) using procedures described by Moser and others (2002a). In 2005, the battery life of tags implanted in lampreys was 302-316 days. Extended life versions of the same tags were used in 2006, with a battery life of 541-561 days. Unique tag codes allowed individual identification of each fish. The tag codes were parsed into eight channels to minimize radio signal collisions and each channel was scanned sequentially. Tagged fish were allowed to recover in aerated fresh water for 2-4 h after surgery, loaded onto a truck, and released $2 \mathrm{~km}$ downstream of the falls, downstream of the first antenna. Lampreys were monitored from the time of release to their last detection in the array or until the following May. We ended monitoring in May because of time constraints and because this was the presumed start of spawning for fish tagged in the previous year. During each week, we also weighed and measured as many as 30 lampreys to describe the general size characteristics of the population. These fish were handled without anesthesia and released upstream of the Project at the Bernert Landing boat ramp. 


\section{Data Processing and Analysis}

Data records (that is, date, time, location, transmission power, receiver and antenna number, channel, and code) were collated with tagging data records (that is, fish size, gender, tagging date, and release time) using computer software (SAS 8.1). Duplicate tag records, radio frequency noise, and erroneous data collected for a tag code before a fish was released were removed prior to analysis. The collated data were then separated by individual fish and manually reviewed for all metrics of interest including travel time, passage time, and route of passage.

We used an approach similar to that outlined in Moser and others (2002b) for analysis of our radio-tracking data. Briefly, records were reviewed for a specific chronological series of events. Event codes were assigned to mark changes in lamprey position (for example, the first detection of a transmitter in the entrance of a fishway leg was coded as an entrance into that leg; subsequent detections at the fishway exit were coded as passage, and so on). We defined a passage event as successful if the fish was detected upstream of the Project by antennas located $1 \mathrm{~km}$ upstream of the falls, by mobile tracking done by us or personnel from the Grand Ronde Tribe (Jeff Baker, Fishery Biologist for the Confederated Tribes of the Grande Ronde, oral commun., November 2006), or by aerial surveys conducted by Clemens and others (2006). For each potential route of passage (that is, the falls or fishways), we calculated passage efficiency as the number of fish that successfully passed divided by the total number of fish that attempted to pass by that route. Overall passage efficiency of lampreys at the Project was defined as the number of fish that successfully passed the Project divided by the number of fish that approached the Project. The time lampreys required to pass the Project was defined as the time from last detection outside a fishway entrance or at the base of the falls to the last detection at the fishway exit or top of the falls. We estimated that fish were near the top of the falls by the strength and duration of sequential signals logged by our antennas covering this area. To identify areas where lampreys were congregating, we calculated the cumulative time (greater than 1 hour) that fish spent in discrete areas, including the I-205 bridge, Blue Heron, the cul-de-sac, and the falls.

\section{Results}

\section{5}

\section{Fish Capture}

From April to September 2005, we collected 1,032 adult Pacific lampreys from the trap and 41 from the base of the falls. Of these, 116 from the trap and 20 from the falls were tagged. Tagged lampreys ranged in size from 57 to $76 \mathrm{~cm}$ and 295 to $760 \mathrm{~g}$ (table 1). Lampreys collected from the falls showed no differences in physical characteristics, sex ratio, or migration behavior relative to lampreys from the trap (except for the number of attempts to pass through the falls; see section on "Attempts to Pass the Falls”) and we therefore include both types of fish in our results below. 


\section{Approach to the Dam}

More than 90 percent of the radio-tagged lampreys we released resumed upstream migration and approached the Willamette Falls Project. The median travel time to the Project was 9 hours and ranged from 1 hour to 148 days (table 2). Lampreys approached the Project primarily at night between 20:00 and 23:00 h (fig. 5). Of the fish that did not return to the Project, seven (two males and five females) were detected downstream of the release site (three fish entered the Clackamas River) and four (two males and two females) were never detected following release.

\section{Upstream Passage}

Of the 125 lamprey that approached the Project, 43 (35 percent) successfully passed over it (table 3). All these fish passed through the fishway. Most lampreys that passed the Project used fishway leg 1 (35 of 43 fish, or 81 percent) and required a median travel time of 23 hours to pass. Seven fish used fishway leg 3 with a median passage time of 4 h hours. Only one fish used fishway leg 2 and it passed in 5 hours. No lampreys passed through the navigation lock. Lampreys passed the Project from early May to mid-October (fig. 6). All fish that passed through fishway legs 2 and 3 did so before midJuly, when the flashboards were installed. Lampreys that used fishway leg 1 showed a peak in passage from mid-August to early September and were the only fish to pass after mid-July. Although there was no passage over the falls, more than 60 percent of the lampreys that approached the Project resided near the falls, often for several days or weeks (see section, “Congregating Areas”). Because of our antenna placement and the Project configuration, we were unable to quantify holding time at fishway entrances.

Passage efficiency varied by route and was lowest at the falls ( 0 percent) and highest at fishway leg 3 (89 percent; fig. 7), the fishway nearest the falls. The passage efficiency for fish using fishway leg 1 - the most common route of passage at the Project - was 59 percent. Efficiency estimates for fishway leg 3 may be biased because the first antenna is midway up the fishway and fish that entered the lower end of the fishway potentially went unrecorded.

Most lampreys made persistent efforts to pass upstream, often making multiple entrances into the fishway or attempts to ascend the falls. Lampreys that did pass the Project migrated upstream rapidly and typically were detected for a few minutes at each of the upstream antennas. Only two fish were detected downstream of the Project after passage — one in late June 2005 and the other in May 2006. Of the 43 lamprey that passed, 26 were detected far upstream of the Project during aerial mobile tracking efforts (Clemens and others, 2006).

\section{Attempts to Pass the Falls}

Lampreys typically ascended the southeast side of the falls in areas covered by antennas 3 and 4, but a few ascended near antenna 5 on the eastern edge of the falls (see fig. 3 ). All lampreys that ascended the falls in 2005 were collected from the trap and not from the falls. Most made their attempts before July (fig. 8), which was before fish were collected from the falls. Of the 17 lampreys that ascended the falls, 12 were detected moving downstream of the Project, one passed the Project through fishway 3, and the other four were last detected at the falls. Two of these remained at the falls until their tags expired in early spring and signals from the other two fish were lost for unknown reasons.

\section{Fish That Did Not Pass}

More than 45 percent of the radio-tagged lampreys that approached the Willamette Falls Project were last detected moving downstream (table 4). More than one-half left the vicinity of the Project by 
the end of September (fig. 9). One of these fish traveled up the Clackamas River. Twenty-four lampreys were last detected in the cul-de-sac and downstream of the falls. Fifteen of these remained there until their radio tag expired in early spring 2006 and the signals of the remaining nine fish were lost for unknown reasons.

\section{Congregating Areas}

Fish that approached the falls after release spent most of their time near the falls (median $=18.5$ days) or in the cul-de-sac (median = 11.4 days; table 5). These were the two areas where fish tended to congregate, and many were monitored for almost a year. Fish that eventually passed the dam spent less time in these areas than fish that did not pass. The installation of flashboards in July reduced the time fish spent at Blue Heron and the cul-de-sac and resulted in fewer fish congregating at the falls (table 5).

\section{6}

\section{Fish Capture}

From April to September 2006, we collected 444 lampreys from the trap and base of the falls. Of these, we tagged 94 from the trap and 13 from the falls. Mean sizes of tagged fish were similar to those in 2005 and ranged from 53 to $74 \mathrm{~cm}$ and 320 to $650 \mathrm{~g}$ (table 1). Again, lampreys collected from the falls showed no differences in physical characteristics, sex ratio, or migration behavior relative to lampreys from the trap. We included lampreys from the falls and lampreys from the trap in our results.

\section{Approach to the Project}

More than 97 percent of the radio-tagged lampreys we released in 2006 resumed upstream migration and approached the Project. Median travel time was 7 hours and ranged from 2 hours to 111days (table 2). Lampreys approached the Project primarily at night between 20:00 and 23:00 hours (fig. 5). Of the fish that did not return to the Project, two were detected downstream of the release site and one was not detected following release.

\section{Upstream Passage}

Passage success was low in 2006 - only 24 (23 percent) lampreys passed the Project (table 3). Most passage (16 fish) occurred in fishway leg 1 before the powerhouse was shut down on June 9 (median passage time was 74 hours). Fish that passed after this date through fishway leg 1 had entered the fishway prior to the shut down (fig. 10). Three fish each passed through fishway legs 2 and 3 and had median passage times of 4 and 5 hours . Two of 19 lampreys that ascended the falls successfully passed upstream. No fish passed through the navigation lock. Passage efficiency varied by route and was lowest at the falls (11 percent) and highest at fishway leg 3 (100 percent; fig. 7). However, we note again that passage efficiency through fishway leg 3 may be biased because the antenna was located midway through the fishway and we do not know, nor can we estimate, the number of fish that may have entered this fishway but fell out. The passage efficiency for fish using fishway leg 1 -the most common route of passage at the Project—was 52 percent. 
The 24 lampreys that passed the Project migrated upstream rapidly and, again, were detected for only a few minutes at the antennas upstream of the falls. Only one fish was detected downstream of the falls after passage (37 days). Mobile tracking by boat in areas upstream of the Project by the Confederated Tribes of the Grand Ronde (CTGR) detected five of our radio-tagged fish. Additionally, a fixed antenna site on the mouth of the Santiam River, maintained by the CTGR, detected a single fish in November 2006.

\section{Attempts and Passage at the Falls}

In 2006, 76 percent of the lampreys that approached the Project resided at the base of the falls, often for several days or weeks (see section, “Congregating Areas”). Nineteen lampreys made attempts to ascend the falls, most occurring before July (fig. 11). On June 28 and July 1, two lampreys passed over Willamette Falls near antenna 4. These lampreys showed similar upstream migration behavior to those that passed through the fishway.

\section{Fish That Did Not Pass}

More than one-half of the radio-tagged lampreys that approached the Project in 2006 were last detected moving downstream (table 4). Two of these fish were last detected in the Clackamas River. More than 60 percent left the Project vicinity by the end of September (fig. 12). Twenty-five lampreys in the falls and cul-de-sac areas had weak, stationary, or lost signals.

\section{Congregating Areas}

Fish that approached the falls after release spent most of their time near the falls (median = 18.13 days; table 6). Most fish tended to congregate in this area, with many being monitored for almost a year. Fish that eventually passed the dam spent much less time at Blue Heron, in the cul-de-sac, and near the falls than fish that did not pass.

\section{Discussion}

Upstream passage of adult Pacific lampreys at the Willamette Falls Project was relatively poor in 2 consecutive years with passage efficiencies generally lower than those reported for lampreys passing dams on the Columbia River (Moser and others, 2002b). Overall passage efficiency of lampreys at the three lowermost dams on the Columbia River (Bonneville, The Dalles, and John Day dams) in 19972000 ranged from about 25 to 80 percent (Moser and others, 2002b). At Bonneville Dam, where all these fish were captured and tagged, passage efficiency ranged from about 37 to 43 percent (Moser and others, 2002b). However, comparing the passage of lampreys at the Project to that at large Columbia River dams is not entirely valid. Dams on the Columbia River are more modern, sometimes have several fishways, receive consistent technological updates and research, and have a greater ability to control spillway flows. Currently, many are being outfitted with lamprey-specific passage devices that can be placed in existing fishways (Moser and others, 2005). In contrast, the Willamette Falls Project is a complex of natural waterfalls, powerhouse, dam, navigation lock, and seasonal flashboards that, because of fishway, paper mill, and other demands, often experiences uncontrolled spill over basalt ledges and shelves of rock, gravel, and woody debris. Thus, the actual passage conditions for lampreys at the Project and at Columbia River dams are quite different. In general, our results, along with those of Moser and others (2002b), confirm that Pacific lampreys have poor passage success at hydropower dams in the Columbia River basin relative to salmonids. This is not surprising considering that all fishways in the basin were designed to facilitate the passage of adult anadromous salmonids and the 
substantial differences in swimming capability between salmonids and lampreys (see Mesa and others, 2003). Our results also indicate that nearly one-half of the lampreys that approached the Project eventually moved back downstream. Reasons for this downstream movement are unknown but may indicate substantial spawning activity occurring downstream of the falls in the lower Willamette River or its tributaries.

Although previous work addressing lamprey passage at the Project reported passage efficiencies similar to ours, results from these studies are not directly comparable due to differences in methods and other factors. For example, Hanson and Mathur (2002) reported that 9 of 47 (19 percent) radio-tagged lampreys passed upstream of the Project, with 2 passing through fishway leg 1 and 7 passing over the falls. However, these authors tagged all their fish on only 3 days in August 2001 and noted that most fish passed over the falls during high spill in November. Using only fish from late August may not be representative of the general population and, in contrast to our results, we never recorded fish passingthrough any route-during the late autumn or winter. A cursory re-analysis of tracking data presented in Hanson and Mathur (2002) suggests that some fish may have ascended to near the top of the falls, but did not pass. The primary congregation areas for lampreys reported by Hanson and Mathur (2002), namely the lower tailrace and falls and the cul-de-sac, were similar to our results. Ward and others (2005) reported 50 percent (6 of 12 fish) of radio-tagged lampreys passed the Project in 2003 and 38 percent (11 of 29) passed in 2004. They noted that, in total, seven fish passed via the fishway, but were unable to determine a route of passage for the other fish. All their fish passed during the summer. Collectively, these studies_-despite their small sample sizes, some methodological problems, and possible reporting errors - substantiate the notion that overall passage success of lampreys at the Project is poor, at least relative to the standards previously discussed.

At this time, specific reasons for the relatively poor passage success of lampreys at Willamette Falls Project are unknown, but one or more of the following may be contributory. First, low flows and water levels at fishway entrances may reduce the ability of lampreys to find or enter them. Impediments in the fishways, such as 90 degree corners, high flows through submerged orifices, or diffuser gratings on the floor also may hinder the ability of lampreys to move through. There also could be unknown delayed tagging effects. Changing environmental conditions, such as flows, water temperature, or day length, and changing Project operations, such as shutting down the powerhouse and installing flashboards, may alter the motivation of fish to migrate. Finally, lampreys that were previously captured, handled, and tagged may show a learned aversion to a fishway.

Our results suggest that low flows and water levels in the tailrace may be significant factors influencing the passage success of lampreys at the Project. In July 2005, when flashboards were installed around the falls and water was diverted to the powerhouse, attraction flow was maintained at the entrance to fishway leg 1 and many fish passed through this route. In fact, the peak of passage occurred over a month later in August. In 2006, however, when the powerhouse was shut down and flows to fishway entrance 1 were reduced, fish passage through this route essentially stopped. Thus, we conclude that maintaining sufficient flow at the entrance to fishway leg 1 is important for fish to locate and enter the fishway. Normally, about $450 \mathrm{ft}^{3} / \mathrm{s}$ of water is supplied from turbine unit 1 of the powerhouse for attraction flow at the entrance to fishway leg 1 . For fishway leg 3 , which has its entrance near the apex of the falls and dam, we surmise that water level at the base of the falls contributes to the low numbers of fish using this route. During low flows, or when the flashboards are installed, there is reduced spill at the horseshoe section of the falls and the tailwater elevation drops. When this occurs, the entrance to this fishway leg can become disconnected with the tailwater and lampreys may have difficulty reaching it. More detailed tracking in this area would help confirm this notion. Construction of a new spillway flow control structure near fishway legs 2 and 3 may help 
alleviate this problem. The entrance to fishway leg 2 is operable at tailwater elevations ranging from 0 to $7 \mathrm{~m}$, thus fish probably have little difficulty entering this fishway entrance. However, there may be other factors influencing passage of lampreys through fishway leg 2.

Although we have not conducted detailed inspections of the fishway at the Project, cursory observations during our work revealed the presence of potential impediments to lamprey passage, such as impediments in the fishways, 90 degree corners, high flows through submerged orifices, or diffuser gratings on the floor. Indeed, Moser and others (2002a, 2002b) noted that sharp corners at entrances or orifices and areas with floor gratings reduced the passage efficiency of lampreys through fishways at Columbia River dams primarily because such areas precluded consistent lamprey attachment.

Modifications such as smoothing and rounding the bulkheads at the entrances of fishways at Bonneville Dam improved lamprey entrance success (Moser and others, 2005). The placement of small steel plates over some area of the floor grates also facilitated lamprey passage over these structures (Moser and others, 2005). Because these same types of structures exist in the fishways at the Project, we surmise that they do impede lamprey passage and recommend modifications such as those implemented at Columbia River dams.

The possibility that delayed tagging effects might influence lamprey passage success at dams is real, but research in this area is sparse. Recent laboratory studies on the effects of implanting lampreys with radio tags indicate that fish recover rapidly after surgery and swimming performance was only mildly compromised (Close and others, 2003; Mesa and others, 2003). However, the short term nature of these laboratory studies and the relatively benign holding conditions may not be representative of conditions in the wild. We are concerned about effects that may occur several days, weeks, or months after surgery, tagging, and release. For example, if lampreys are demersal swimmers-even some of the time - the possibility exists for them to rub their incision on rocks or other substrates, pull out sutures, and expose the wound to pathogens and subsequent infections. We have seen at least one of our radiotagged fish at the counting window in the fishway of the Project with missing sutures, although the radio tag was still in place. Lampreys with infected incisions, if this does occur, may be less motivated to migrate or show reduced performance capacity, thus contributing to poor passage success. We are currently conducting laboratory studies designed to assess long-term effects of radio tagging lampreys. Ongoing work at some Columbia River dams evaluating the passage success of PIT-tagged lampreys relative to radio-tagged fish also may be insightful.

The influence of environmental variables such as temperature and river flow on lamprey migrations may be significant. Various researchers, cited in Hardisty and Potter (1971), found associations between water temperatures and timing of upstream movements, size of the spawning run, and the cessation of movement. However, many of these studies also emphasized the importance of high water levels or flows on lamprey migrations. Because temperature and flow are auto-correlated, it is difficult to discern the relative effects of each on lamprey behavior and migrations. Indeed, our results from 2005 showed that the peak of lamprey passage occurred in August during the warmest temperatures (as high as $23^{\circ} \mathrm{C}$ ) and lowest flows. From September through mid-October, a time of decreasing temperatures and relatively consistent low flows, passage of lampreys was reduced. Recent work by Robinson and Bayer (2005) showed that upstream movement of radio-tagged lampreys in the John Day River, Oregon, ceased in the autumn (median date was September 12), a time of decreasing temperature, day length, and low flows. Thus, there may be thresholds in some environmental variables beyond which lampreys will initiate holding behavior and our results may reflect this. We surmise, however, that difficulties associated with passage at the Project result in more fish holding behavior downstream of the Project relative to the pre-impoundment era. During the days of Lewis and Clark, many more fish probably migrated past the falls and initiated holding behavior farther up in the basin. 
Some historical photographs suggest that passage conditions for upstream migrating fish at Willamette Falls were relatively benign along the western shoreline, an area currently occupied by the dam.

Whether fish develop an aversion to migrating through a fishway after they have been captured, tagged, and released downstream is unknown but possible. The poor experience fish had when they were first captured may make them reluctant to enter a fishway a second time, which would affect passage efficiency. However, several lines of evidence suggest that aversion to a fishway by lampreys probably is a minor factor in their overall passage success. First, our results, and those of Moser and others (2002b), clearly show that a high percentage of tagged fish (more than 90 percent) re-approach the Project, indicating a high motivation to migrate and minimal aversion. Second, many fish in both studies made several entrances to fishways or attempts to pass the Project, which is counter to an aversion hypothesis. Finally, Moser and others (2002b) showed that lampreys tagged at Bonneville Dam and released either upstream or downstream of the dam entered the fishway at the next upstream dam (The Dalles) with equal success. Different levels of experience with fishways at one dam did not influence passage through fishways at another dam. It seems that future studies would benefit by capturing and tagging fish in areas well downstream of any dams.

Because of the falls, passage conditions for fish at the Project are unusual and challenging. Historically, the falls probably were an important route of passage for lampreys, particularly in the late spring and early summer when flows were decreasing and temperatures were mild. Further, as we mentioned earlier, photographs of the river prior to impoundment show an area adjacent to the west shoreline that was lower gradient and possibly provided easier passage upstream. Today, however, few lampreys pass the Project through the falls. We documented only two fish that passed upstream through the falls, although almost 40 fish migrated some distance up the falls. Lampreys that ascended the falls could be differentiated by their unique detection signatures. Specifically, these fish had simultaneous detections at antennas located at the falls (high power level) and upstream of the Project (moderately low power levels). Although we can not pinpoint the exact distance fish traveled up the falls, fish that were detected simultaneously at falls and upstream antennas were likely at the top of the falls where upstream antennas have line of sight to the tags. Although specific reasons for the poor passage success at the falls are unknown, they probably are related more to the concrete apron surrounding the falls than to the flashboards. In 2005, most fish that ascended the falls but did not pass did so prior to installation of the flashboards. In 2006, a year when no flashboards were installed, most ascents of the falls occurred prior to mid-July. The two fish that did pass through the falls in 2006 did so in early July. Thus, because most attempts by lampreys to pass upstream through the falls occurred prior to installation of flashboards, the boards themselves probably have little influence on passage success. Installation of the flashboards, however, does divert significant flow away from the falls, which may render the falls less attractive to lampreys for passage. The concrete apron surrounding the perimeter of the falls, with its near 90-degree vertical corners and slick, periphyton-covered surface, probably presents challenging conditions for effective lamprey passage. Ward and others (2005) also discuss the influence of Project operations on lamprey staging areas and passage. Future research should target this issue and explore remedial measures.

Passage efficiency and use of the three different fishway legs by lampreys at the Project varied. Fishway leg 1 received the most use, passed the most fish, and had overall efficiencies of 52 and 59 percent in the 2 years of study. Fishway leg 2 received a moderate amount of use (25 fish) but had passage efficiencies of less than 25 percent. Fishway leg 3 received the fewest fish but had the highest efficiency-from 89 to 100 percent. The lampreys' high level of use of fishway leg 1 probably is due to the fishway's close proximity to the falls and the presence of sufficient and consistent attraction flow from the powerhouse. The entrance to this fishway leg is in the cul-de-sac area — an area that many 
lampreys visited and congregated in before entering the fishway or continuing to the falls. The importance of attraction flow near the entrance to this fishway leg was evident in 2006 when the powerhouse was shut off, flows decreased, and lamprey passage through this route ceased. Reasons for the poor passage efficiency at fishway leg 2 are unclear and require further study. Many fish clearly enter this fishway leg but do not travel a significant distance upstream, indicating that problems with passage may be near the entrance. Because we could not place an underwater antenna at the entrance to fishway leg 3, passage data for this route of passage probably are conservatively biased. Our antenna in this leg of the fishway was placed at about the midpoint of its length. Thus, fish detected on this antenna had already traveled a significant distance up the fishway leg and were likely to continue and eventually pass. We do not know how many other fish entered this fishway leg but did not make it to the antenna site, which of course has implications for calculating passage efficiency. Placing antennas at the entrances to fishway leg 3 should be a priority for future research.

The time required by lamprey to pass through a fishway depended on which fishway they used. Travel times through fishway leg 1 (352 $\mathrm{m}$ in length) were notably longer than those through fishway legs $2(153 \mathrm{~m})$ or $3(226 \mathrm{~m})$. This most likely is due to the length of fishway leg 1 relative to the legs 2 and 3 , but it also may reflect a greater number of impediments to passage (for example, sharp corners or floor grates) in leg 1 that increase the travel time of lampreys. The passage times reported here are substantially less than those for lampreys passing Bonneville Dam (range of times $=4.4-5.7$ days; Moser and others, 2002b). However, Moser and others (2002b) calculated passage time as the time from first detection outside a fishway entrance to the last detection at the fishway exit. Our passage times were based on when the fish last entered the fishway. Thus, the two studies calculated passage times differently and are not directly comparable.

In both years of our study, nearly 50 percent of the lampreys that approached the Project were last detected migrating downstream, and about one-half of these left before the end of September. The destinations of these fish are largely unknown but a few were detected in the Clackamas River. The range in time that fish stayed near the Project before moving downstream was considerable and went from a few days to almost a year. The reasons for this downstream movement are unclear but may be related to finding new areas for extended holding, spawning activity, or perhaps accidental straying. For example, it is conceivable that some lampreys migrating to Willamette Falls strayed and actually were destined to migrate up the Columbia River. Although current thinking suggests that lampreys have little or no fidelity to their natal streams like Pacific salmon do (Bergstedt and Seelye, 1995), research on this topic is not extensive, particularly for lampreys in the west. Future radio-tagging studies of lampreys in the Willamette River should expand the area of tracking, either by increasing the number of automated radio-telemetry sites or by using mobile tracking. Receivers should be placed in key locations at Bonneville Dam to determine whether fish from Willamette Falls eventually migrate up the Columbia River. Information on the behavior of lampreys that migrate to Willamette Falls and eventually leave could have implications for evaluating overall passage at the Project. For example, it may be that a portion of the population of lampreys at Willamette Falls is actually destined to spawn downstream of the falls or in other tributaries of the Columbia River. Research aimed at understanding the purpose and nuances of the downstream movements of lampreys at Willamette Falls seems prudent. 
In summary, the Willamette Falls Project has relatively poor passage success of Pacific lampreys (when compared to Columbia River dams) and probably impacts production in the upper Willamette River basin. This is not surprising considering the passage problems lampreys encounter at Columbia River dams and elsewhere, including sea lamprey in the Great Lakes (Haro and Kynard, 1997) and river lamprey in Europe (Laine and others, 1998). Passage conditions at the Willamette Falls Project may be even more arduous for lamprey because of the falls themselves and how they have been incorporated into the Project (for example, the concrete apron on the crest of the falls). The Willamette River basin was an important contributor to lamprey production in the Columbia River basin (Kostow, 2002). Large congregations of lamprey are observed each year at the falls and a personal and tribal harvest is permitted by the State of Oregon. The viewing window at the exit of the fishway has large accumulations of lampreys each season (April through July). Our results indicate that efforts should be directed to facilitate improved upstream passage of lampreys at the Project to conserve and restore decreasing populations. Some actions can be undertaken now, such as modifying fishway entrances and channels to minimize any impediments to lamprey passage (for example, rounding or smoothing corners, putting plates over floor gratings). More research is necessary to understand the specifics of problems associated with fishway entrances and passage over the falls. Monitoring the area in the immediate vicinity of the concrete apron and the entrance to fishway leg 3, if possible, would be insightful to address the multiple hypotheses posed in these areas. Construction of a new flow-control structure on the southwest face of the falls may benefit lamprey passage over the falls and at fishway legs 2 and 3. Because lamprey passage at the Willamette Falls Project seems to occur primarily through the fishways, efforts to implement more quantitative counts of lampreys passing the Project would be useful. Future studies aimed at reducing flows in the fishways at night to facilitate lamprey passage, as has been done at Bonneville Dam (Moser and others, 2005), might prove beneficial at the Willamette Falls Project. Finally, more research is needed on the long-term effects of surgically implanting lampreys with radio tags to determine how well tagged fish represent the population at large and whether tagging influences sexual maturation and spawning or leads to delayed mortality.

\section{Acknowledgments}

We thank Portland General Electric (PGE), the U.S. Fish and Wildlife Service (USFWS), the Bureau of Reclamation, and the Confederated Tribes of the Grand Ronde (CTGR) for cooperatively funding this study; Dan Domina (formerly of PGE) and Chris Karchesky of Normandeau Associates, David Heintzman and Tim Shibahara of PGE, Doug Baus of the USFWS, Dave Nelson of the Bureau of Reclamation, and Jeff Baker and Kelly Dierkson of the CTGR for technical, administrative, field, and financial assistance; Phillip Haner, Tyler Mitchell, Brad Liedtke, Collin Smith, and Theresa Liedtke of the CRRL for technical assistance with radio-telemetry equipment; and numerous colleagues at the CRRL for their cheerful and tireless work in the field. 


\section{References Cited}

Bergstedt, R.A., and J.G. Seelye, 1995, Evidence for lack of homing by sea lampreys: Transactions of the American Fisheries Society, v. 124, p. 235-239.

Clemens, B.J., Magie, R J., Young, D.A., Mesa, M.G., Li, H.W., and Schreck, C.B., 2006, Aerial tracking of Pacific lamprey in the Willamette Falls River Basin, Oregon: Portland, Oreg., Annual Report for 2005 to the Bureau of Reclamation.

Close, D.A., Fitzpatrick, M., Li, H., Parker, B., Hatch, D., and James, G., 1995, Status report of the Pacific lamprey (Lampetra tridentata) in the Columbia Basin: Portland, Oreg., Bonneville Power Administration Project Number 94-026.

Close, D.A., Fitzpatrick, M.S., Lorion, C.M., Li, H.W., and Schreck, C.B., 2003, Effects of intraperitoneally implanted radio-transmitters on the swimming performance and physiology of Pacific lampreys: North American Journal of Fisheries Management, v. 23, p. 1184-1192.

Hanson, B.N., and Mathur, D., 2002, Congregation areas and movements of adult Pacific lamprey in the vicinity of the Willamette Falls Project, fall 2001-spring 2002: Report prepared for Pacific Gas and Electric Co., Portland, Oreg., Blue Heron Paper Co., Oregon City, Oreg., and the Willamette Falls Project Fisheries, Aquatics and Terrestrial Workgroup.

Hardisty, M.W., and Potter, I.C., 1971, The general biology of lampreys, in Hardisty, M.W., and Potter, I.C., eds., The biology of lampreys: New York, Academic Press, p. 127-206.

Haro, A., and Kynard, B., 1997, Video evaluation of passage efficiency of American shad and sea lamprey in a modified ice harbor fishway: North American Journal of Fisheries Management, v. 17, p. 981-987.

Kostow, K., 2002, Oregon lampreys: natural history, status, and analysis of management issues: Portland, Oreg., Oregon Department of Fish and Wildlife.

Laine, A., Kamula, R., and Hooli, J., 1998, Fish and lamprey passage in a combined denil and vertical slot fishway: Fisheries Management and Ecology, v. 5, p. 31-44.

Mesa, M.G., Bayer, J.M., and Seelye, J.G., 2003, Swimming performance and physiological responses to exhaustive exercise in radio-tagged and untagged Pacific lampreys: Transactions of the American Fisheries Society, v. 132, p. 483-492.

Moser, M.L., Matter, A.L., Struehrenberg, L.C., and Bjornn, T.C., 2002a, Use of an extensive radio receiver network to document Pacific lamprey (Lampetra tridentata) entrance efficiency at fishways in the Lower Columbia River, USA: Hydrobiologia, v. 483, p. 45-53.

Moser, M.L., Ocker, P.A., Stuehrenberg, L.C., and Bjornn, T.C., 2002b, Passage efficiency of adult Pacific lampreys at hydropower dams on the lower Columbia River, USA: Transactions of the American Fisheries Society, v. 131, p. 956-965.

Moser, M.L., Ogden, D.A., and Peery, C., 2005, Migration behavior of adult Pacific lamprey in the lower Columbia River and evaluation of Bonneville Dam modifications to improve passage, 2002: Fish Ecology Division, Northwest Fisheries Science Center, National Marine Fisheries Service, National Oceanic and Atmospheric Administration.

Renaud, C.B., 1997, Conservation status of Northern Hemisphere lamprey (Petromyzontidae): Journal of Applied Ichthyology, v. 13, p. 143-148.

Robinson, T.C., and Bayer, J.M., 2005, Upstream migration of Pacific lampreys in the John Day River, Oregon: behavior, timing, and habitat use: Northwest Science, v. 79, p. 106-119. Ward, D.L., Koloszar, J.A., Pribyl, A.L., and Tinus, E.S., 2005, Movements of adult Pacific lamprey near Willamette Falls, 2003-04: Clackamas, Oreg., Oregon Department of Fish and Wildlife. 
Table 1. Number, mean ( $\pm \mathrm{SD}$ ) length, range of lengths (cm), mean weights $(\mathrm{g})$, and sex ratio of Pacific lampreys that were sampled, radio-tagged, and successfully passed at the Willamette Falls Project, Oregon, 2005-06.

[SD, standard deviation; cm, centimeter; g, gram; M:F, male:female]

\begin{tabular}{|c|c|c|c|}
\hline \multicolumn{2}{|l|}{ Category } & 2005 & 2006 \\
\hline \multicolumn{2}{|l|}{ Sampled } & 594 & 444 \\
\hline & Mean length & $61(5)$ & $59(5)$ \\
\hline & Range & $40-76$ & $44-75$ \\
\hline & Mean weight & 405 (88) & 384 (79) \\
\hline & Range & $190-760$ & $200-650$ \\
\hline \multirow[t]{6}{*}{ Tagged } & & 136 & 107 \\
\hline & Mean length & 66 (4) & $65(4)$ \\
\hline & Range & $57-76$ & $53-74$ \\
\hline & Mean weight & 481 (74) & 469 (57) \\
\hline & Range & $295-760$ & $320-650$ \\
\hline & M:F & $60: 76$ & $42: 65$ \\
\hline \multirow[t]{6}{*}{ Passed } & & 43 & 24 \\
\hline & Mean length & $67(4)$ & $64(3)$ \\
\hline & Range & $59-76$ & $59-71$ \\
\hline & Mean weight & 504 (83) & 455 (67) \\
\hline & Range & $350-760$ & $320-650$ \\
\hline & M:F & $21: 22$ & 9:15 \\
\hline
\end{tabular}

Table 2. Number of Pacific lampreys that were radio-tagged and released downstream of the Willamette Falls Project, Oregon, the number that approached the Project, and the median, range, and standard deviation of travel times (in hours unless specified) from release to first detection, 2005-06.

\begin{tabular}{lll}
\hline Category & 2005 & 2006 \\
\hline Number released & 136 & 107 \\
Number approached & 125 & 104 \\
Median travel time to falls & 9 & 7 \\
Range of travel times & $1-148$ & $2-111$ \\
Standard deviation of travel time & 29 & 25 \\
\hline
\end{tabular}


Table 3. Number of radio-tagged Pacific lampreys that passed over the Willamette Falls Project, Oregon, and the median, range, and standard deviation (SD) of passage time (in hours unless specified) by route, 2005-06.

[NA, not applicable; d, day]

\begin{tabular}{cll}
\hline Category & 2005 & 2006 \\
\hline Total number passed & 43 & 24 \\
Number passed via fishway 1 & 35 & 16 \\
Median passage time & 23 & 74 \\
Range & $3-11 \mathrm{~d}$ & $8-13 \mathrm{~d}$ \\
SD & 71 & 89 \\
Number passed via fishway 2 & 1 & 3 \\
Median passage time & 5 & 5 \\
Range & NA & $3-22$ \\
SD & NA & 11 \\
Number passed via fishway 3 & 7 & 3 \\
Median passage time & 4 & 4 \\
Range & $1-4$ & $4-20$ \\
SD & 2 & 9 \\
Number passed via falls & 0 & 2 \\
\hline
\end{tabular}

Table 4. Location of last detection of radio-tagged Pacific lamprey at the Willamette Falls Project, Oregon, 200506.

\begin{tabular}{lll}
\hline Category & 2005 & 2006 \\
\hline Tagged & 136 & 107 \\
Number that approached & 125 & 104 \\
Upstream & 41 & 23 \\
Downstream (I-205 or below) & 61 & 56 \\
Clackamas River & 1 & 2 \\
Other & 23 & 25 \\
Number that did not approach & 11 & 3 \\
Clackamas River & 3 & 1 \\
Undetected & 4 & 1 \\
\hline
\end{tabular}


Table 5. Median, mean, and range of time (days) spent by radio-tagged Pacific lampreys in areas of the Willamette Falls Project, Oregon, 2005.

[Data are shown for fish that passed the project, for those that did not, and times before and after the installation of flashboards]

\begin{tabular}{|c|c|c|c|c|c|c|}
\hline Category & Area & Median & Mean & Min & Max & $\mathrm{n}$ \\
\hline All & \multirow[t]{5}{*}{ I-205 } & 0.38 & 5.54 & 0.04 & 96.63 & 49 \\
\hline Passed & & 0.54 & 1.71 & 0.04 & 9.04 & 12 \\
\hline Did not pa & & 0.38 & 6.75 & 0.04 & 96.63 & 37 \\
\hline Pre-flashbc & & 0.29 & 2.63 & 0.04 & 36.92 & 23 \\
\hline Post-flashb & & 0.71 & 8.13 & 0.04 & 96.63 & 26 \\
\hline All & \multirow[t]{5}{*}{ Blue Heron } & 4.33 & 41.42 & 0.04 & 256.25 & 44 \\
\hline Passed & & & & & & 0 \\
\hline Did not pa & & 4.29 & 41.42 & 0.04 & 256.25 & 44 \\
\hline Pre-flashbc & & 7.00 & 56.42 & 0.08 & 234.79 & 22 \\
\hline Post-flashb & & 0.92 & 26.46 & 0.04 & 256.25 & 22 \\
\hline All & \multirow[t]{5}{*}{ Cul-de-sac } & 11.42 & 32.67 & 0.04 & 276.04 & 64 \\
\hline Passed & & 4.46 & 5.38 & 0.04 & 17.08 & 24 \\
\hline Did not pa & & 16.83 & 49.00 & 0.04 & 276.04 & 40 \\
\hline Pre-flashbc & & 12.63 & 39.21 & 0.04 & 276.04 & 30 \\
\hline Post-flashb & & 9.42 & 26.88 & 0.04 & 196.13 & 34 \\
\hline All & \multirow[t]{5}{*}{ Falls } & 18.54 & 53.04 & 0.08 & 297.83 & 67 \\
\hline Passed & & 14.79 & 13.08 & 4.17 & 23.42 & 8 \\
\hline Did not pa & & 21.83 & 58.42 & 0.08 & 297.83 & 59 \\
\hline Pre-flashbc & & 18.83 & 52.58 & 0.08 & 297.83 & 46 \\
\hline Post-flashb & & 17.21 & 54.04 & 0.13 & 251.83 & 21 \\
\hline
\end{tabular}

Table 6. Median, mean, and range of time (days) spent by radio-tagged Pacific lampreys in areas of the Willamette Falls Project, Oregon, 2006.

[Data are for fish that passed the project, for those that did not, and for times before and after the installation of flashboards]

\begin{tabular}{lllllll}
\hline Category & Area & Median & Mean & Min & Max & $\mathrm{n}$ \\
\hline All & I-205 & $\mathbf{0 . 7 5}$ & $\mathbf{2 8 . 2 9}$ & $\mathbf{0 . 0 8}$ & $\mathbf{2 6 7 . 0 4}$ & $\mathbf{1 5}$ \\
Passed & & 0.21 & 0.21 & 0.13 & 25.92 & 2 \\
Did not pass & & 1.21 & 32.63 & 0.08 & 267.04 & 13 \\
All & Blue Heron & $\mathbf{1 . 5 0}$ & $\mathbf{2 3 . 2 5}$ & $\mathbf{0 . 0 4}$ & $\mathbf{1 3 8 . 3 3}$ & $\mathbf{2 9}$ \\
Passed & & 1.00 & 1.00 & 1.00 & 1.00 & 1 \\
Did not pass & & 1.75 & 24.04 & 0.04 & 138.33 & 28 \\
All & Cul-de-sac & $\mathbf{2 . 4 2}$ & $\mathbf{6 . 3 3}$ & $\mathbf{0 . 0 4}$ & $\mathbf{6 2 . 0 4}$ & $\mathbf{2 9}$ \\
Passed & & 3.88 & 4.21 & 0.13 & 8.08 & 5 \\
Did not pass & & 1.88 & 6.50 & 0.04 & 62.04 & 24 \\
All & Falls & $\mathbf{1 8 . 1 3}$ & $\mathbf{4 8 . 0 4}$ & $\mathbf{0 . 0 8}$ & $\mathbf{3 4 4 . 0 0}$ & $\mathbf{7 9}$ \\
Passed & & 8.00 & 8.33 & 2.17 & 14.08 & 8 \\
Did not pass & & 20.25 & 52.54 & 0.08 & 344.00 & 71 \\
\hline
\end{tabular}




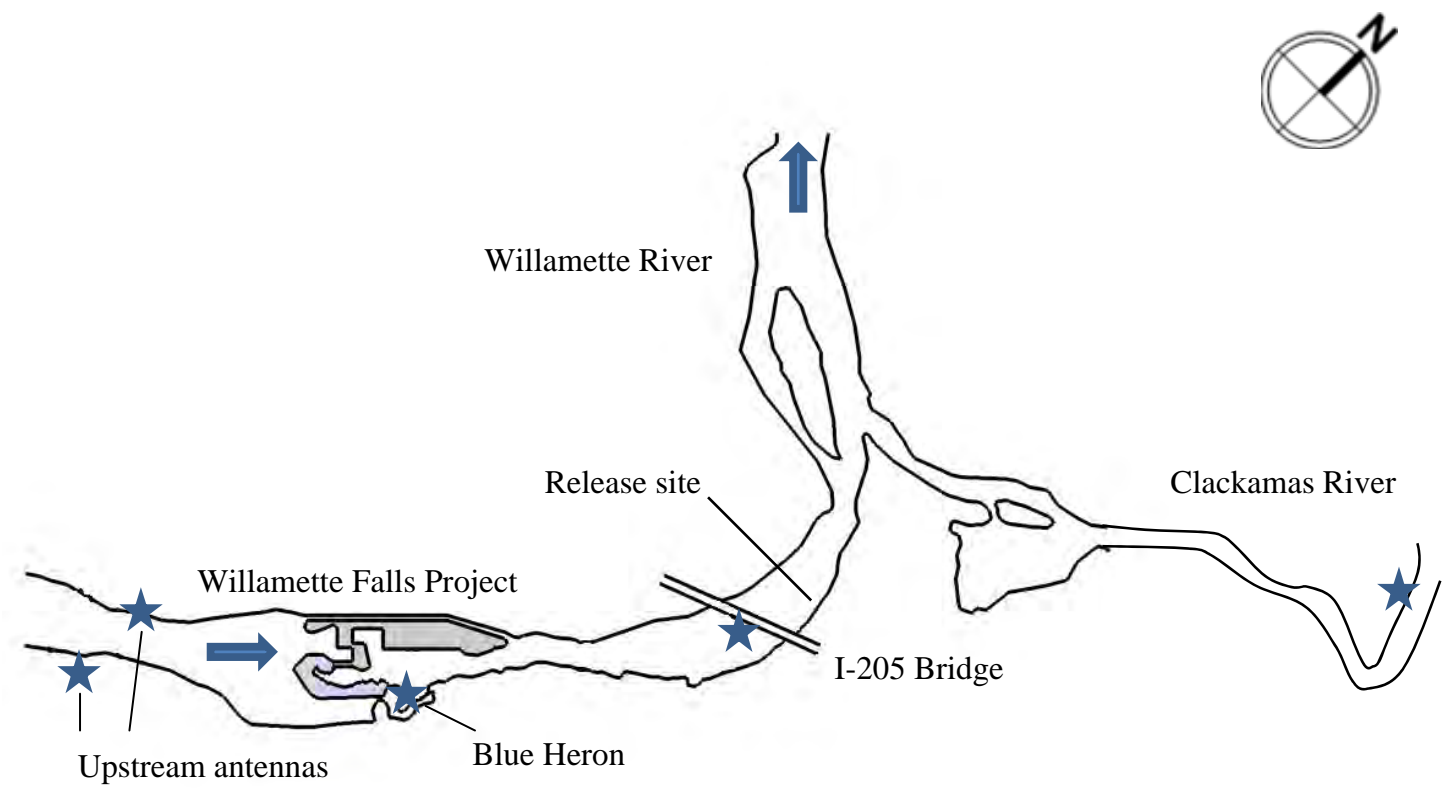

$1 \mathrm{~km}$

Figure 1. Overview of study area on the Willamette River, Oregon. Stars indicate aerial antennas outside of the immediate vicinity of the Willamette Falls Project. Blue arrows indicate direction of flow. 


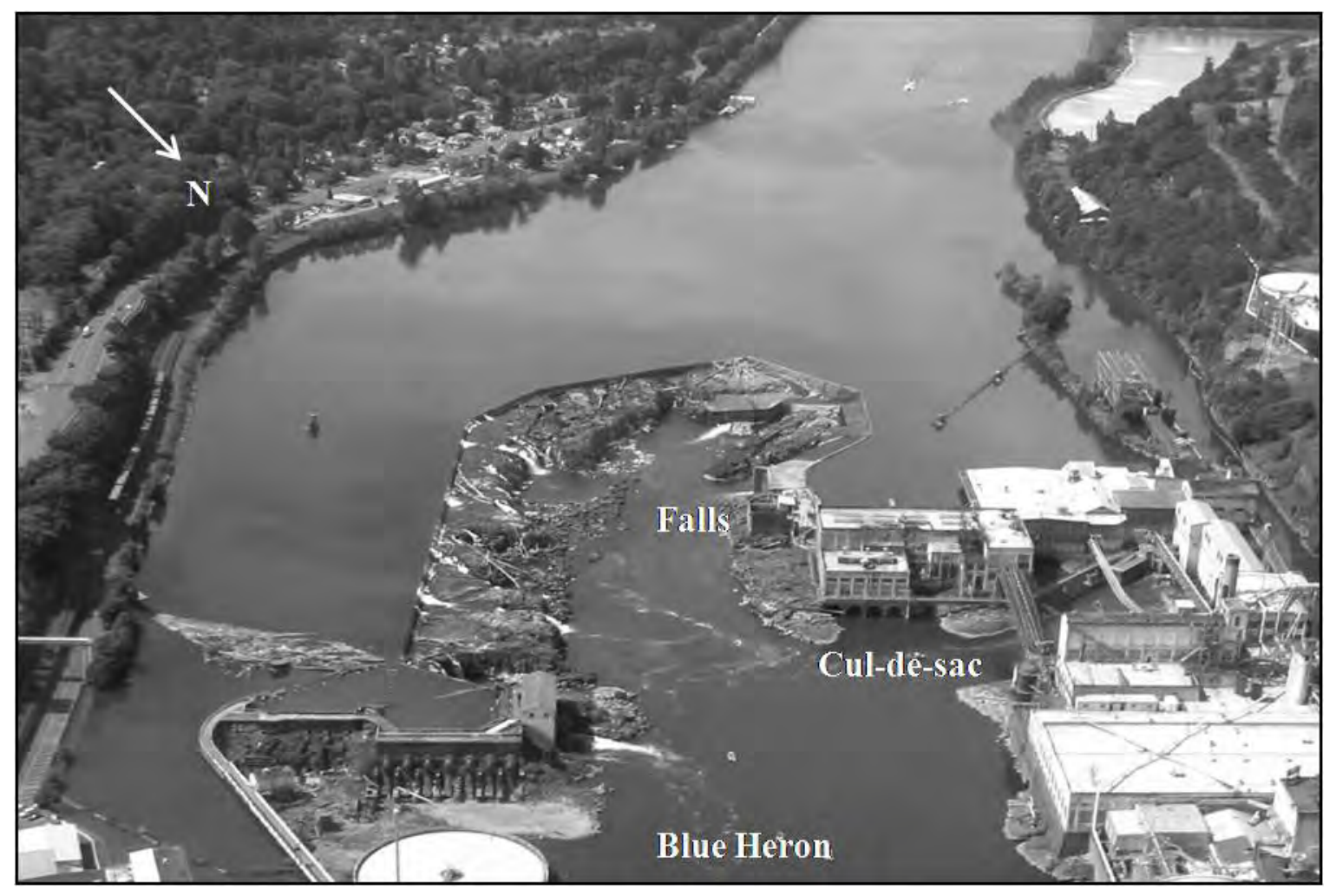

Figure 2. Photograph of the Willamette Falls Project, Oregon, showing three general areas monitored during telemetry studies, 2005-07. Photograph provided courtesy of Portland General Electric (photographer and origin unknown). 


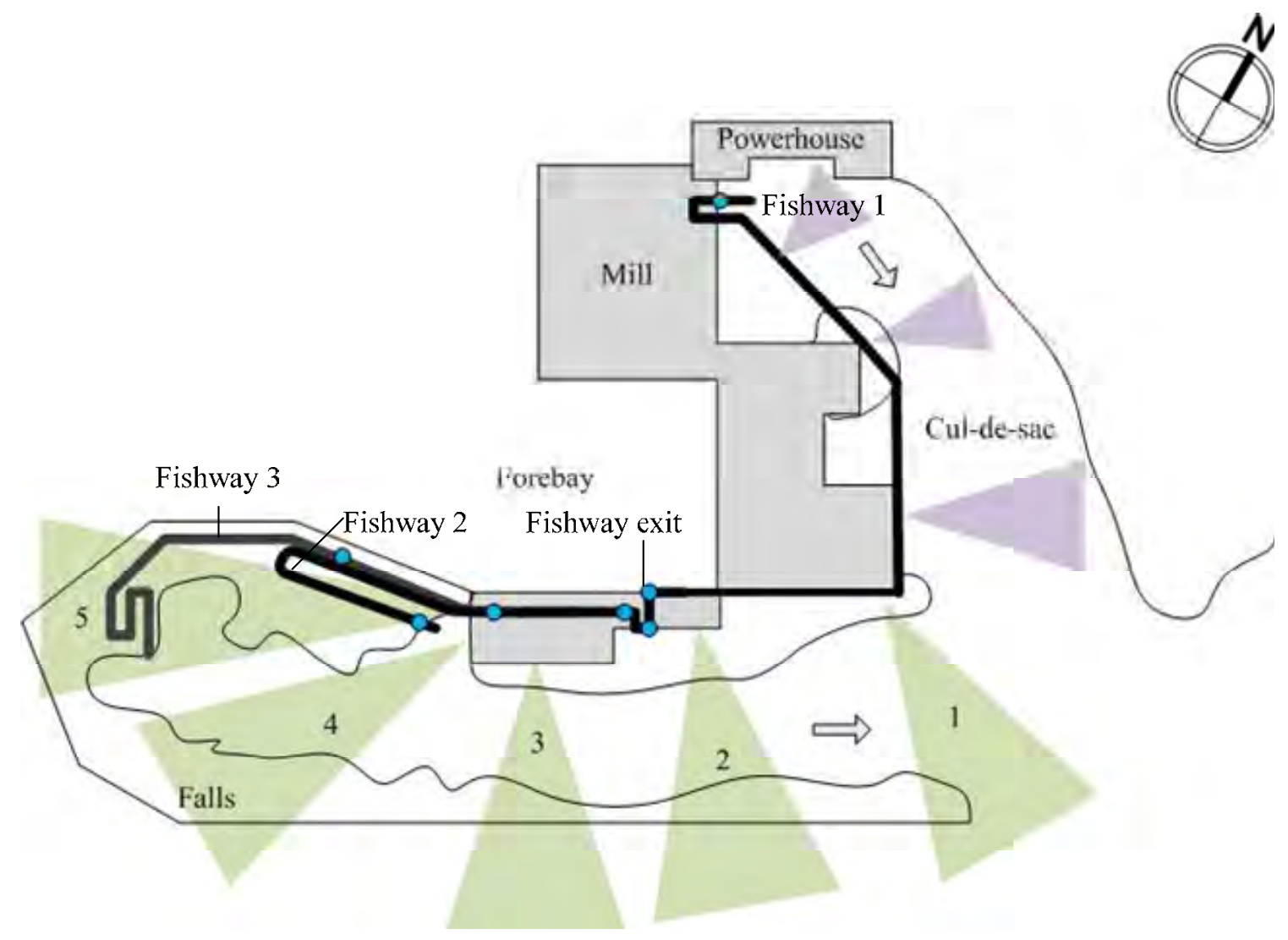

Figure 3. Schematic drawing of the Willamette Falls Project, Oregon, showing the location of aerial (triangles) and underwater (circles) antennas for the telemetry array used for monitoring lamprey passage. Arrows indicate direction of flow of the Willamette River. 


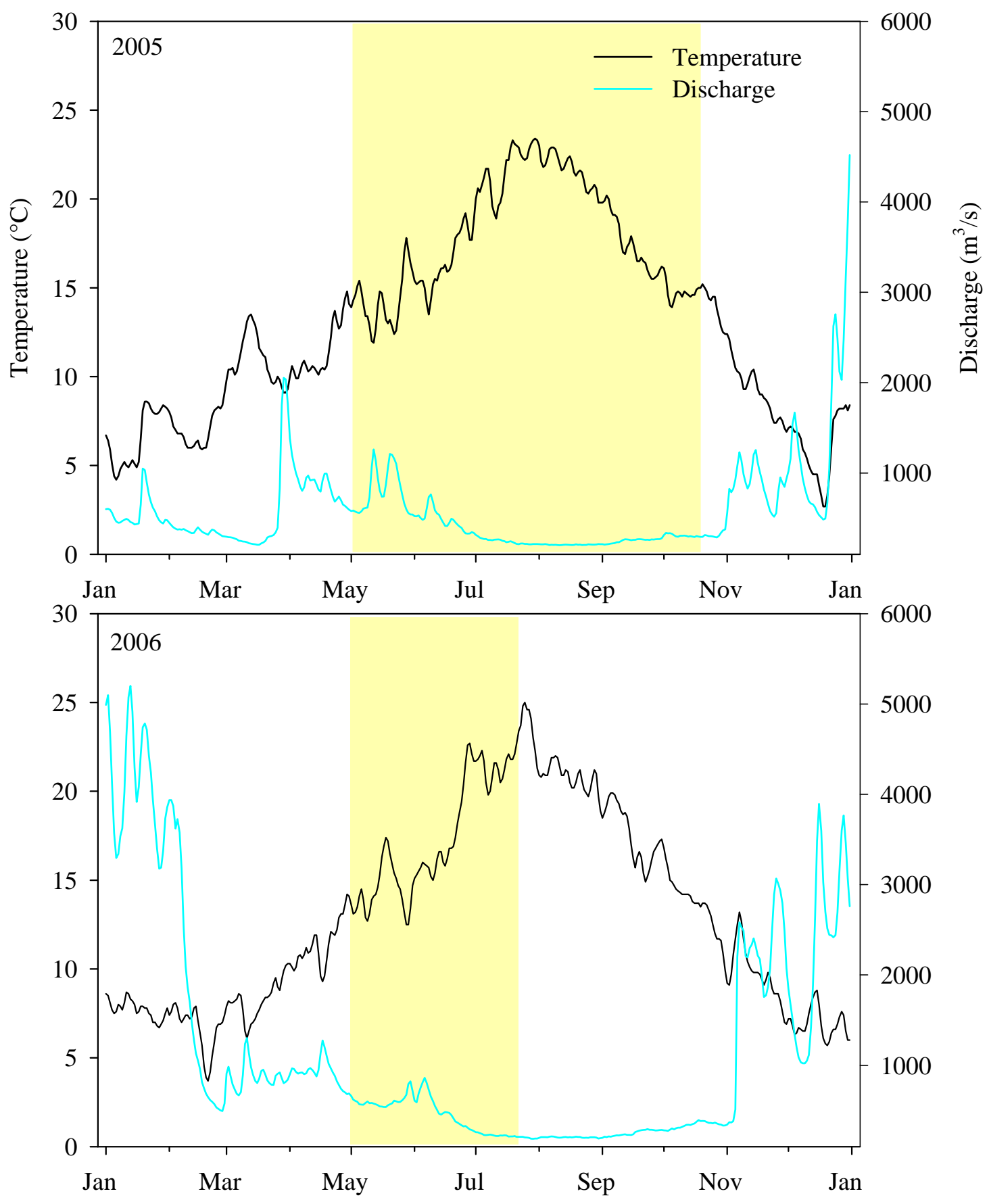

Figure 4. Daily mean discharge $\left(\mathrm{m}^{3} / \mathrm{s}\right)$ and water temperature $\left({ }^{\circ} \mathrm{C}\right)$ at the Willamette Falls Project for 2005-06. The yellow shaded areas represent the period of radio-tagged Pacific lamprey passage for each year. 


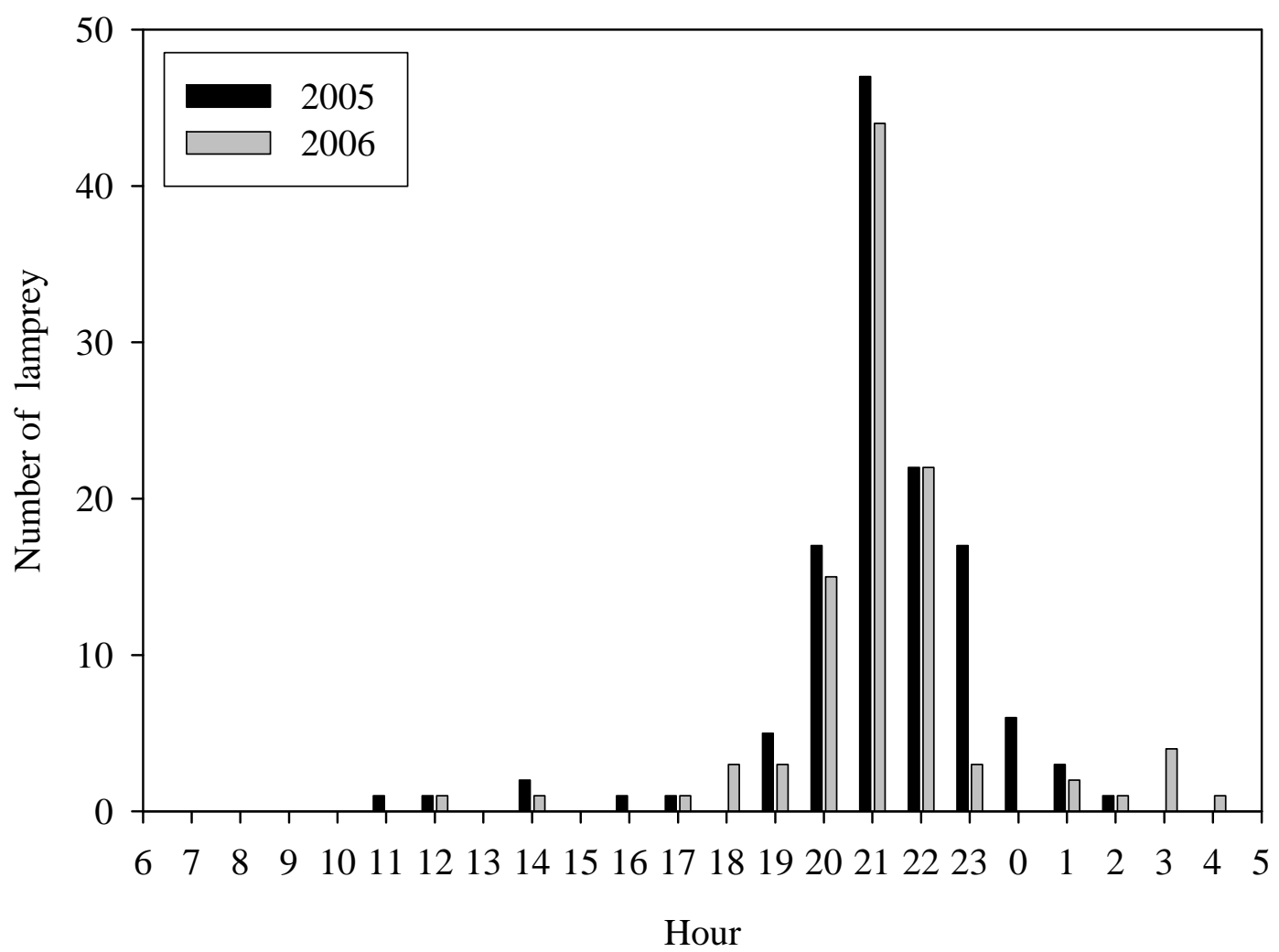

Figure 5. Hour of the day or night (Pacific Standard Time) when radio-tagged Pacific lampreys were first detected as they approached the Willamette Falls Project, Oregon, 2005-06. 

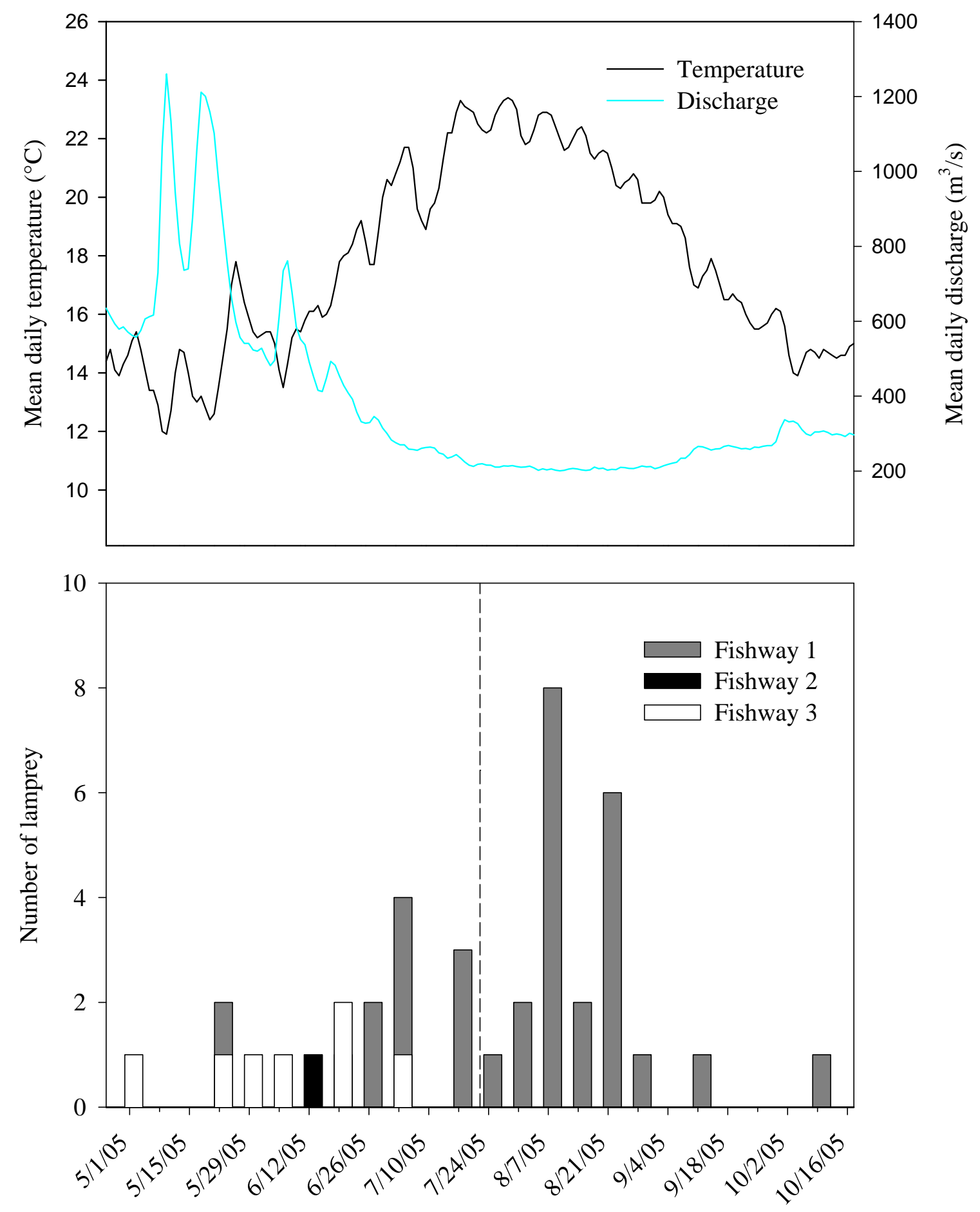

Figure 6. Mean daily temperature $\left({ }^{\circ} \mathrm{C}\right)$, discharge $(\mathrm{kcfs})$, and lamprey passage by week at the Willamette Falls Project, Oregon, 2005. The dashed line represents installation of flashboards at the falls on July 21. 


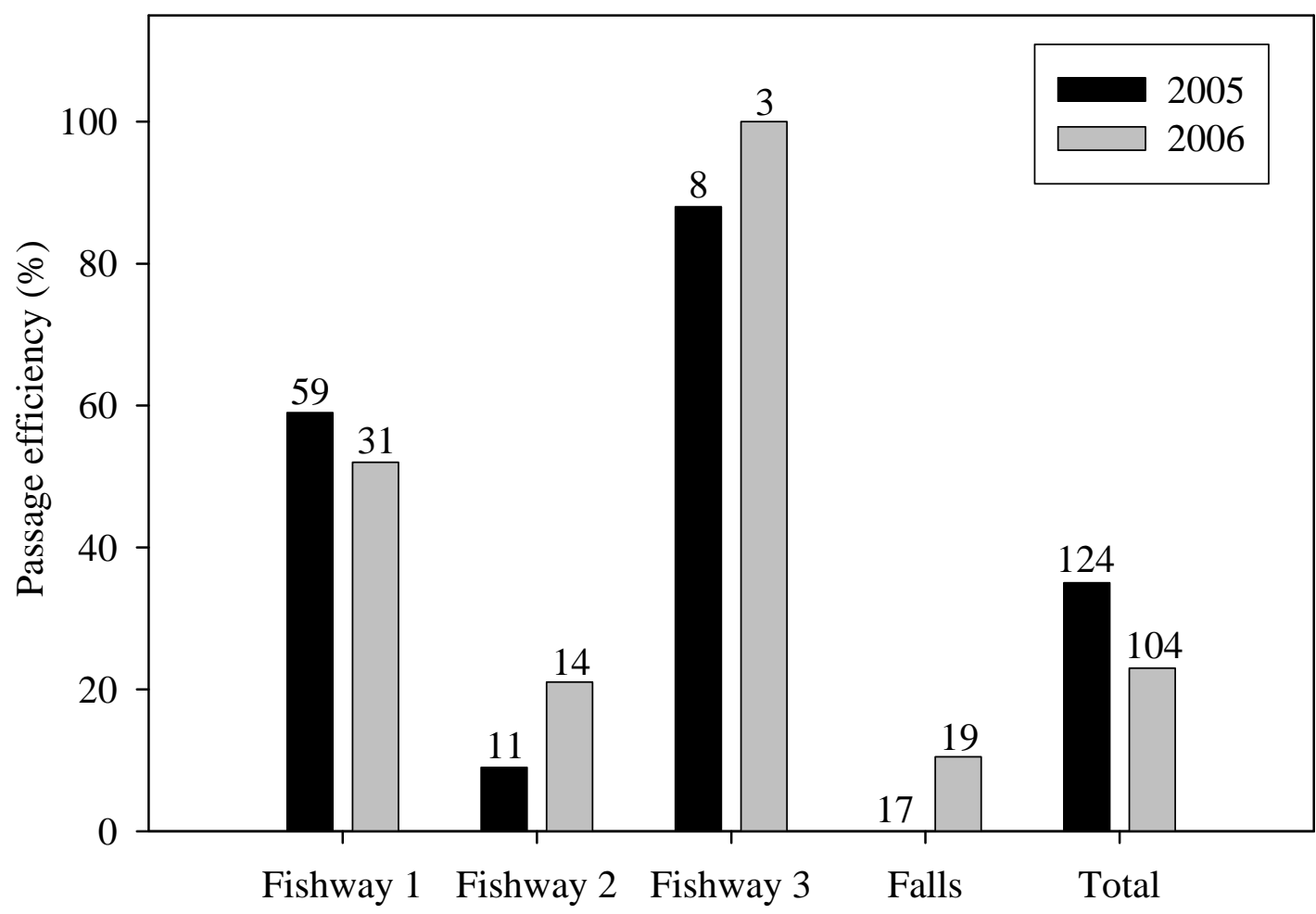

Figure 7. Passage efficiency of Pacific lampreys by route (that is, the fishways or the falls; the number of fish that successfully passed divided by the number that attempted to pass) and for lampreys overall (the number that successfully passed divided by the number that approached the Project) at the Willamette Falls Project, Oregon, 2005-06. The number of lampreys that attempted to pass each route or that approached the Project is shown above each bar. 


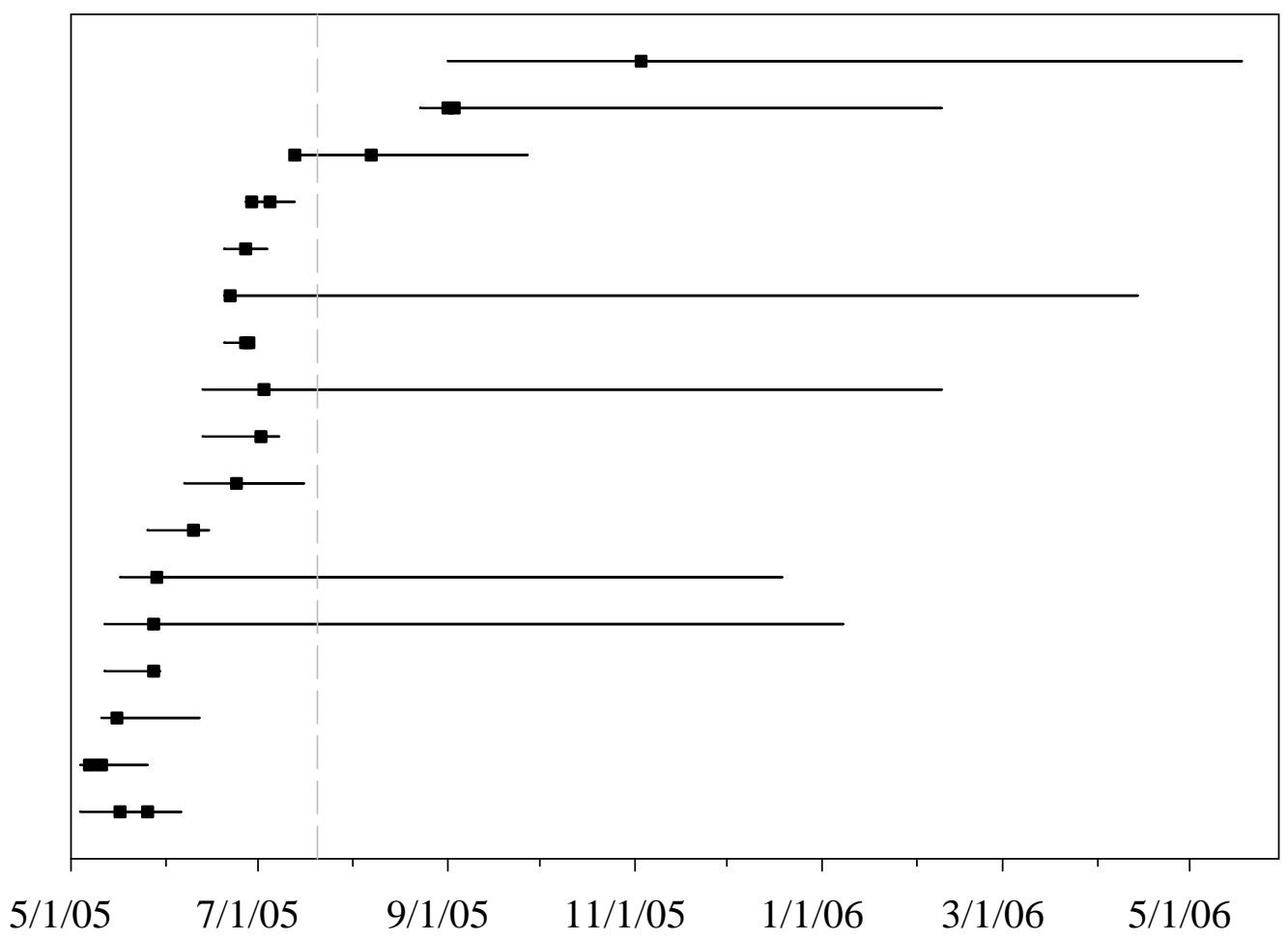

Figure 8. Attempts by 17 radio-tagged Pacific lampreys to ascend Willamette Falls, Oregon, 2005. Horizontal lines represent a lamprey's date of release until its final detection. The squares denote the date when a fish attempted to pass through the falls. Flashboard installation began on July 21, 2005, and is denoted with a dashed line. 


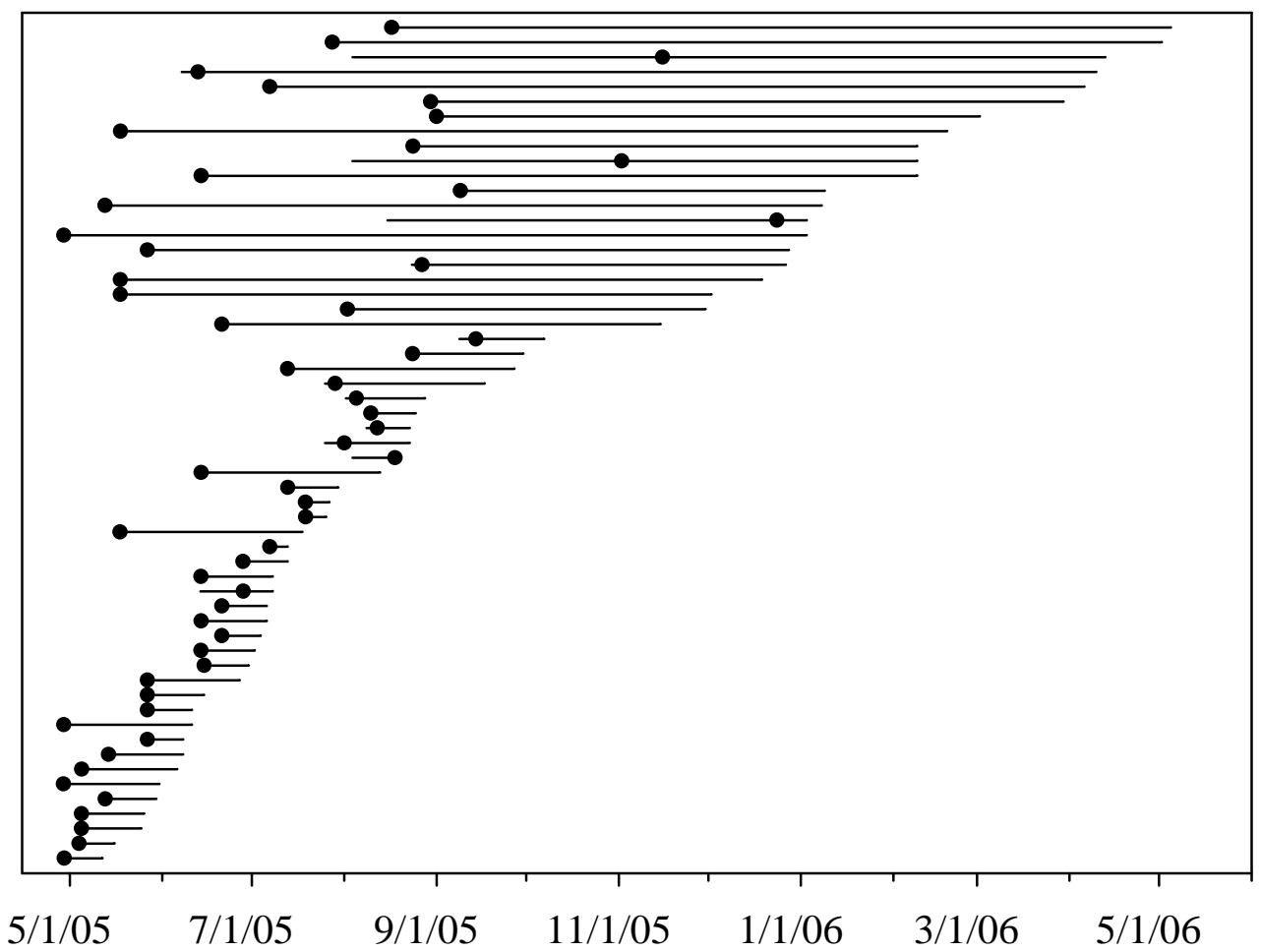

Figure 9. Duration of detection at Willamette Falls Project for Pacific lampreys that did not pass the Project and eventually migrated downstream in 2005. Each circle and line represents a single fish. The circles denote when a lamprey first approached the Project. The horizontal lines represent the date of release until last detection downstream of the Project at the I-205 bridge. 

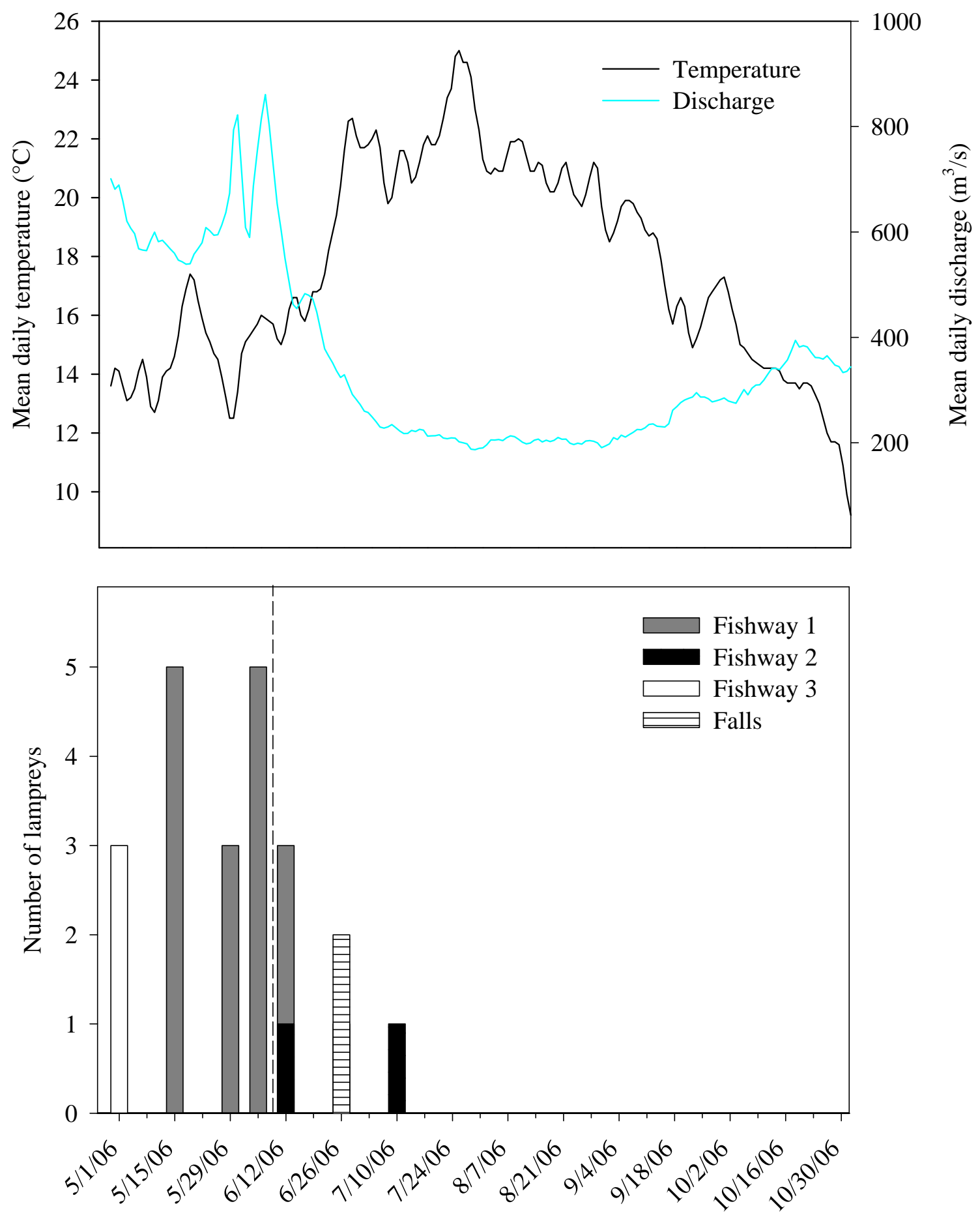

Figure 10. Mean daily temperature $\left({ }^{\circ} \mathrm{C}\right)$, discharge $\left(\mathrm{m}^{3} / \mathrm{s}\right)$, and lamprey passage by week at the Willamette Falls Project, Oregon, 2006. The dashed line denotes closure of the T.W. Sullivan Powerhouse on June 9. 


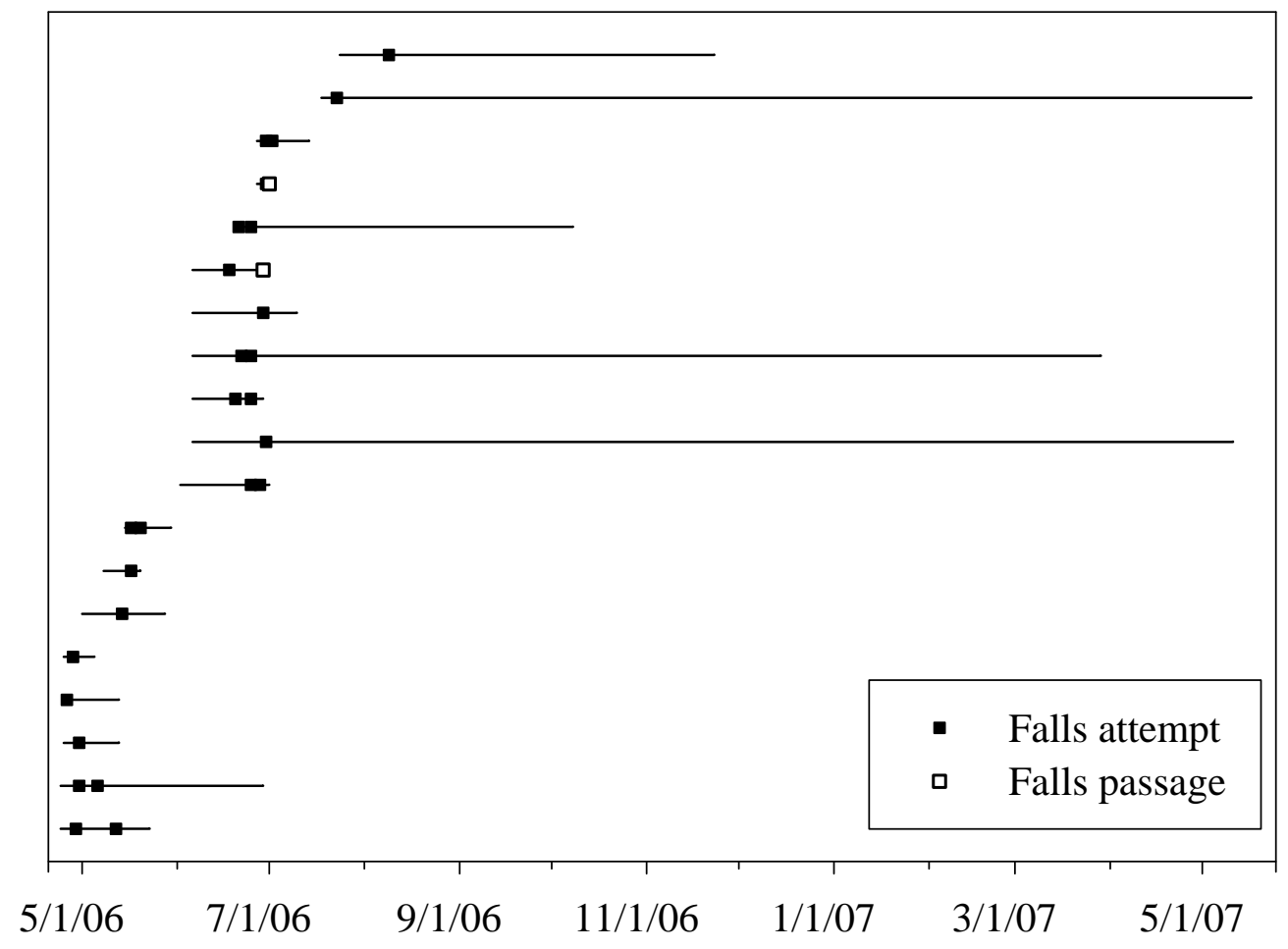

Figure 11. Attempts by 19 radio-tagged lampreys to ascend Willamette Falls, Oregon, 2006. Horizontal lines represent a lamprey's date of release until its final detection. The squares denote the date when a fish attempted to pass through the falls. No flashboards were installed in 2006. 
Publishing support provided by the U.S. Geological Survey Publishing Network, Tacoma Publishing Service Center

For more information concerning the research in this report, contact the Director, Western Fisheries Research Center

U.S. Geological Survey

6505 NE 65th Street

Seattle, Washington 98115

http://wfrc.usgs.gov/ 


\section{$\mathbb{1}$ 劳}

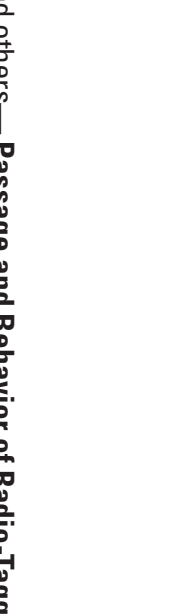

